\title{
EFFECT OF AWARENESS, KNOWLEDGE AND ATTITUDE OF TAXPAYERS TAX COMPLIANCE FOR TAXPAYERS IN TAX SERVICE OFFICE BOYOLALI
}

\author{
Tutik Lestari $^{1)}$, Monot Wicaksono ${ }^{2)}$ \\ STIE-AAS, Central Java, Indonesia \\ Email:monot.wicaksono@yahoo.com
}

\begin{abstract}
Tax compliance is a major factor affecting tax revenues. To determine the level of compliance of taxpayers in meeting their tax obligations can be seen from the achievement of revenue targets. This research aims to analyzing the influence of taxpayers' awareness, knowledge of taxation, and taxpayers' attitude influential on of docility taxpayers in KPP Pratama Boyolali. Convenience sampling was conducted in this research as a method. Data obtained in the form of primary data questionnaire distributed in KPP Pratama Boyolali and data obtained secondary from KPP Pratama Boyolali. Taxpayers taken as sampled was taxpayers who came to KPP Pratama Boyolali who have NPWP good taxpayers people personally and the body was handed SPT in KPP Pratama Boyolali. This research used Multiple Regression analysis tool. The result of research shows that awareness taxpayers influential significantly against of docility taxpayers. The knowledge of the tax is not influential significantly against of docility taxpayers The attitude of the taxpayers significantly influences taxpayer compliance.
\end{abstract}

Keywords: taxpayer awareness, knowledge of taxation, attitude of the taxpayer on tax compliance.

\section{Introduction}

Economy Indonesia can not realize a prosperous society. Many national development is still lacking, even public facilities such as health centers, roads, village offices and other public institutions that need to be repaired. Society often complain and are not satisfied with the government's policy in terms of national development. The condition is influenced by the disobedience of the taxpayer that is the community itself in paying taxes. A state income tax that will be returned to the community in the form of public facilities. But many people do not know about it. Society needs to know the role of tax knowledge correctly. It is very important for the progress of the tax in Indonesia.

Taxation has a variety of rules that have been set in legislation. Every taxpayer is required to understand all the rules applicable taxes. But not all tax payers who has full access to information. The low number of registered taxpayers in Boyolali also due to the lack of public awareness and the tax benefits of ownership of Taxpayer Identification Number (TIN). Because during this time many people who argue that reciprocity taxes through the development of common infrastructure and service facilities that either have not done evenly and the results have not been fully felt by the entire community. So that people tend to evasion of 
tax payment that starts with not register himself as a taxpayer.

Tax collection in Indonesia is based on the basic Act 1945 section 23 A which states that taxes and other charges for the purposes of coercive state governed by the Act. Tax collection is the embodiment of devotion obligations and role of the taxpayer to directly and jointly implement the necessary tax obligations for financing the state and national development.

Tax collection system in Indonesia has undergone a change of official assessment system becomes self assessment system since the tax reform in 1983. The self assessment tax collection system is a system that gives authority, trust, responsibility to taxpayers calculate profit, calculate, pay, and report own amount of tax to be paid (Waluyo, 2008). Awareness, knowledge, attitudes taxpayers and compliance of taxpayers is an important factor of the system implementation. Self-assessment system in the Law on taxation is stated in Article 12 of Law KUP every taxpayer is obliged to pay the tax due in accordance with the provisions of tax legislation, by not relying on their tax assessments (SKP).

One of the obligations of the taxpayer is enrolled to obtain a Taxpayer Identification Number (TIN). Taxpayer Identification Number (TIN) ownership is a requirement for each taxpayer if it has met subjective and objective requirements under the provisions of the tax law. In addition to its obligations, Taxpayer Identification Number (TIN) also diatar background by the various functions of TIN as the identity of the taxpayer. Once the taxpayer has a tax ID, then all taxation activities undertaken by the taxpayer will be recorded and monitored by the Directorate General of Taxes through the Taxpayer
Identification Number (TIN) as a means of tax administration.

Awareness taxpayer in paying taxes on time will affect the high and low on tax compliance. Consciousness is the state knows, understands the circumstances and feel. Therefore, doing the tax awareness is to understand the attitude taxpayer or an individual taxpayer to understand the meaning, function and purpose of the payment of taxes.

Knowledge of tax rules is important to cultivate a submissive behavior, however, because the taxpayer must comply if they do not know the tax laws, then how taxpayers can submit tax returns on time if they do not know when the time to maturity in the submission of tax returns.

If the taxpayer considers that the rights and obligations comparable in the sense that the balance between its obligations as a taxpayer and the rights that can be obtained will be mandatory apajak tend to be more compliant in relation to the treatment of every taxpayer. If taxpayers feel that the tax justice has been applied to all taxpayers by not differentiating treatment between taxpayer with individuals, large taxpayers with tax payers small in the sense that all taxpayers are treated fairly then every taxpayer tends to run his tax obligations with good or otherwise give rise to compliance within the taxpayer. In the tax payments of the taxpayers must obey the tax laws. In order for the tax revenue for the state to reach the target.

People active role in supporting national development is indispensable, particularly the taxpayer. People as a taxpayer would help provide a contribution to the state in taxes. Compliance is very important to promote Indonesian taxation. Because the tax compliance determines state revenues. If the 
taxpayer does not comply with the existing tax laws, the impact is very big for the Indonesian economy.

\section{Research Methods}

This research is quantitative research that solves the problem with popularity figures to be taken given the conclusions and suggestions.

Basically, doing the research is to answer the problem. Quantitative research is based on the preliminary study of the object under study to get that really matter. Problems can not be obtained from behind the counter, therefore, should be explored through a preliminary study with empirical facts. So that researchers can explore the issue properly, the investigator must master the theory through reading various references. Furthermore, so that the problem can be answered with either the problem is formulated specifically.

The method used in this research is to use the survey method, survey method is a method of research which uses questionnaire as the primary instrument for collecting data. Because the validity of the data is very dependent on the "honesty" of respondents.

\subsection{Population Research.}

The population used in this study is a registered taxpayer in the Primary Tax Service Office Boyolali and is still considered effective tax wajip. While the research sample of 100 taxpayers registered in Tax Service Office Boyolali. Decent size in this study, according Sugiyono (2012: 133) is between 30 and 500 so that the number of samples in this study can be used.

\subsection{Data Research}

Data used in this study, primary data and secondary data. Sources of primary data in this study was obtained directly from taxpayers in Tax Service Office Boyolali. This data is a questionnaire that was filled out by the taxpayer as respondent.

Secondary data in this study is that the data that is already available and is obtained directly on Tax Service Office Boyolali both published and unpublished. Data obtained include, a brief history of the tax office pratama work areas of Tax Service Office Boyolali Boyolali, vision and mission, organizational structure, functions and duties of the position of the tax office pratama Boyolali.

\subsection{Research Variables}

\subsubsection{Independent Variables}

Factor is the variable that is measured, manipulated or selected by the researchers to determine their relationship to a phenomenon observed and the independent variables are variables that can affect the dependent variable.

a. Awareness Paying Taxes (X1)

Awareness of the taxpayer is a condition in which the taxpayer know, understand, and implement tax regulations properly, voluntary, and earnestly to fulfill their tax obligations. Some of the things that concern the Director General of Tax in building awareness and concern of others, namely: to socialize, providing ease of tax obligations and improve service quality, improve the image of good governance, provide educational knowledge of taxation, Law enforcement, building public confidence in the tax and realize the program of census taxation national. 
b. Knowledge of Taxation (X2)

Knowledge of taxation is the ability of a taxpayer to know the tax laws be it a matter of tax rates based on the laws that they will pay and the tax benefits that would be useful for their lives (Utomo, 2011). Knowledge of tax laws (terms) concerning payment of taxes is: have a Taxpayer Identification Number (TIN), fulfill the rights and tax obligations, to understand the tax penalty, to understand the non-taxable income (taxable income), Taxable Income and tax rates, and know the rules taxation through socialization and training of taxation that they follow (Fikriningrum, 2012).

c. Taxpayer Attitude (X3)

The attitude of the taxpayer can be interpreted as a question or evaluative consideration of the taxpayer, whether favorable or unfavorable about the object, person or event. If taxpayers feel that the tax fairness has been applied to all taxpayers by not distinguishing between taxpayers' treatment of small and large taxpayer then each taxpayer will tend to run their tax obligations properly.

\subsubsection{Dependent Variables}

The variable that is affected or which become due from the independent variable. This variable is the main focus of the study. Variable is the value observed and measured to determine the influence of the independent variables.

Compliance pay taxes is Tax Return (SPT) in the last 3 years, the submission of tax returns the tax period of not more than 3 times and not consecutively, have no tax arrears, the financial statements audited by a public accountant or agency financial oversight of government revenues are reasonable, and never a criminal in the field of taxation.
Tax compliance has an important role in the tax collection system in Indonesia to implement self-assessment system. With a high level of compliance means the taxpayer have to voluntarily pay taxes, so as to increase the acceptance of the State of Indonesia.

Variable measurement of awareness and taxpayer compliance using ordinal scale with Likert scale measurement techniques with the following pattern:

Table 1. Likert Scale And Weights Criteria Answers

\begin{tabular}{|l|l|l|}
\hline $\begin{array}{l}\text { Types } \\
\text { Questions }\end{array}$ & Type Answer & Weight \\
\hline Positive & Strongly Disagree (STS) & 1 \\
& Disagree (TS) & 2 \\
& Ragu (R) & 3 \\
& Agree (S) & 4 \\
& Strongly Agree (SS) & 5 \\
\hline Negative & Strongly Disagree (STS) & 5 \\
& Disagree (TS) & 4 \\
& Ragu (R) & 3 \\
& Agree (S) \\
& Strongly Agree (SS) & 1 \\
\hline
\end{tabular}

Source: Data are processed 2016

\subsection{Data Analysis Methods}

\subsubsection{Test Validity and Reliability}

According to Ibn Hajar (1996: 160), the quality of the instrument is determined by two main criteria: reliability and validity. The validity of an instrument according to show how far he can measure what is to be measured. While reliability showed the level of consistency and accuracy of measurement results. To test whether the list of questionnaires made based on the indicators that exist in each of the study variables, both independent variables and the dependent variable (valid) and reliable (reliable) then used two test tools that test the validity and reliability testing. 


\section{a. Test Validity}

Analisis validity of an analysis conducted to measure whether the instruments used in the research is truly able to represent all aspects regarded as a conceptual framework. Testing the validity of using the Pearson product moment correlation test with SPSS. Instrument be valid if the number $r$ count $>r$ table.

Test the validity of this will be known whether or not the grain valid questions with respect to the target accuracy, the accuracy of the amount, timeliness, accuracy rates, administrative accuracy and whether there is an increase in the welfare of society.

Validity test is done in order to determine the validity of the questionnaire. Test the validity of the questionnaire by using the technique of Pearson Product Moment Correlation (Nugroho, 2012). If $r$ count $>\mathrm{r}$ table means that the item is valid.

\section{b. Test Reliability}

Reliability test is used to measure that the instrument is free of misperceptions that produce consistent results and can be used in different conditions. Measurement reliability in the study done by one shot (measurement once). Cronbach alpha reliability test using SPSS program. A constructs or variable is said to be reliable if the value of Cronbach Alpha> 0,600 (Ghozali 2006 in Nugroho, 2012).

From this reliability test will be known that the questionnaire will produce data that is consistent or not, so that each of the questions in relation to the target accuracy, timeliness, accuracy quantity, price accuracy, precision and social welfare administration declared reliable,

\subsubsection{Normality Test}

Data normality test is done to see that the data terdestribusi normally or not. As it is known that $\mathrm{T}$ test and $\mathrm{F}$ test assumes that the value of the residuals follow a normal distribution. A better method is to look normal probability plots comparing the cumulative distribution of real data with a cumulative distribution of the normal distribution.

\subsubsection{Test Multicolinearity}

Multicolinierity test aims to test whether the regression model found a correlation between independent variables (independent). To detect the presence or absence multicoloniarity in the first regression model, the value of tolerance, both of variance inflation factor (VIF). Cutoff value that is commonly used to indicate the presence multicoloniarity is tolerance values $<0.10$ or equal to VIF> 10 (Nugroho, 2012).

\subsubsection{Test Heteroskidastity}

Heteroscedasticity test aims to test whether the regression model occurred inequality variance of the residuals of the observations kepengamatan another. To detect the presence or absence of heteroscedasticity in the regression model can be used in several ways, one of them with glejser test.

\subsubsection{Hypothesis Testing t Test}

The t-test was used to test the effect of each each independent variable (cash flow from operating activities, cash flows from investing activities and cash flows from financing activities) to the dependent variable (financial performance). The measures used are as follows:

a. Determining the composition of the hypothesis

Ho: $\beta 1=0$, there is no significant influence of cash flow from operating activities, cash 
flows from investing activities and cash flows from financing activities on the dependent variable (financial performance) together.

Ha: $\beta 1=0$, there is significant influence betweencash flow from operating activities, cash flows from investing activities and cash flows from financing activities on the dependent variable (financial performance) together.

b. Determining the significant level $\alpha=5 \%$ To determine acceptance or rejection Ho, then the calculation results of significance (sig) compared to significant level of 0.05 . If sig 0.05 then Ho is rejected, which means there is a significant influence of the independent variable on the dependent variable, and vice versa if sig 0.05 means that there is no significant influence of the independent variable on the dependent variable. Another way to determine acceptance or rejection of Ho, is by comparing $\mathrm{t}$ arithmetic with $\mathrm{t}$ table. If $\mathrm{t} t$ table then Ho is rejected, which means there is a significant influence on the independent variable on the dependent variable, and vice versa if $t \quad t$ table which means that there is no significant effect of independent variables on the dependent variable.

\subsubsection{Significant Simultaneous Test (F Test )}

F statistical test aims to test the effect of all independent variables or free (cash flow from operating activities, cash flows from investing activities and cash flows from financing activities) together or bonded to the dependent variable (financial performance). This test is performed with SPSS 17. The steps of the test are:

a. Determining the composition of the hypothesis
Ho: $\beta 1=\beta 2=\beta 3=\beta 4=\beta 5=0$, there is no significant influence ofcash flow from operating activities, cash flows from investing activities and cash flow from financing activities of financial performance together.

Ho: $\beta 1 \neq \beta 2 \neq \beta 3 \neq \beta 4 \neq \beta 5 \neq 0$, there is significant influence betweencash flow from operating activities, cash flows from investing activities and cash flow from financing activities of financial performance together.

b. Determining significant level of $\alpha=5 \%$

To determine acceptance or rejection Ho, then the calculation results of significance (sig) compared to significant level of 0.05 . If sig 0.05 , then Ho is rejected, which means there is a significant influence of the independent variable on the dependent variable, and vice versa if sig 0.05 , meaning there is no significant influence of the independent variable on the dependent variable. Another way to find Ho is accepted or rejected by comparing the $\mathrm{F}$ arithmetic with $\mathrm{F}$ table. If $\mathrm{F}$ arithmetic $\mathrm{F}$ table then Ho is rejected, which means there is a significant influence of independent variables together on the dependent variable, and vice versa, if $\mathrm{F}$ count $\mathrm{F}$ table then $\mathrm{Ho}$ is accepted, which means there is no significant effect of independent variables together to variable dependent.

c. The coefficient of determination (R2)

This test is performed to determine how much influence the independent variable (cash flow from operating activities, cash flows from investing activities and cash flows from financing activities) to the dependent variable (financial performance).

Coefficient of determination is between 0 and 1 . The smaller the value of $\mathrm{R} 2$ which means the ability of independent variables is very limited. R2 is said to be good if it is 
getting close to 1 . If $\mathrm{R} 2$ is equal to 1 means that the independent variable perfect effect on the dependent variable. Meanwhile, if R2 is equal to 0 , then there is no influence of the independent variable on the dependent variable.

\section{Hypothesis Testing Results}

\subsection{Validity of Test Results}

Data analysis was performed on this research is descriptive analysis and multiple linear regression model. The available data for the dependent variable is the profitability (ROA) and the independent variables consist of Cash and Accounts Receivable Turnover Turnover.

Table 2. Variable Awareness Test Validity Paying Taxes

\begin{tabular}{|c|c|c|c|}
\hline No. & $r_{\text {Count }}$ & $\mathrm{r}_{\text {Table }}$ & Information \\
\hline 1 & 0.634 & 0.279 & valid \\
\hline 2 & .631 & 0.279 & valid \\
\hline 3 & 0,747 & 0.279 & valid \\
\hline 4 & 0.727 & 0.279 & valid \\
\hline 5 & 0.727 & 0.279 & valid \\
\hline
\end{tabular}

Source: Primary data were processed in 2016

Based on the above table it can be concluded that the questions for the variable has a value consciousness of paying taxes $r_{\text {count }}>r_{\text {table. }}$. So that the questions are valid consciousness of paying taxes.

Table 3.Validity of Test Results Variable Knowledge Taxpayers

\begin{tabular}{|l|l|l|l|}
\hline No. & r Count & r Table & Information \\
\hline 1 & 0.647 & 0.279 & valid \\
\hline 2 & 0.608 & 0.279 & valid \\
\hline 3 & 0.505 & 0.279 & valid \\
\hline 4 & 0,427 & 0.279 & valid \\
\hline 5 & 0,703 & 0.279 & valid \\
\hline
\end{tabular}

Source: Primary data were processed in 2016

Based on the above table it can be concluded that the questions for mandatory knowledge variable has a value $r_{\text {count }}>r_{\text {table }}$, so that the questions taxpayers overall knowledge valid.
Table 4.Validity of Test Results Variable Taxpayer Attitude

\begin{tabular}{|l|l|l|l|}
\hline No. & \multicolumn{1}{|c|}{$\mathrm{r}_{\text {count }}$} & \multicolumn{1}{c|}{$\mathrm{r}_{\text {table }}$} & \multicolumn{1}{c|}{ Information } \\
\hline 1 & 0.698 & 0.279 & valid \\
\hline 2 & 0.707 & 0.279 & valid \\
\hline 3 & 0.588 & 0.279 & valid \\
\hline 4 & .864 & 0.279 & valid \\
\hline 5 & .798 & 0.279 & valid \\
\hline
\end{tabular}

Based on the above table it can be concluded that the questions for the variables attitude taxpayer whole grains questions rhitung value $>r_{\text {table. }}$. So that the questions taxpayers overall attitude valid.

Table 5.Validity of Test Results Variable Taxpayer Compliance

\begin{tabular}{|l|l|l|l|}
\hline No. & $\mathrm{r}_{\text {count }}$ & $\mathrm{r}_{\text {table }}$ & Information \\
\hline 1 & 0.717 & 0.279 & valid \\
\hline 2 & 0.867 & 0.279 & valid \\
\hline 3 & .778 & 0.279 & valid \\
\hline 4 & 0.912 & 0.279 & valid \\
\hline 5 & 0.705 & 0.279 & valid \\
\hline
\end{tabular}

Source: Primary data were processed in 2016

Based on the above table it can be concluded that the questions on tax compliance variable has a value $r_{\text {count }}>r_{\text {table }}$. So that the questions are valid tax compliance.

\subsection{Reliability Test Results}

Reliability tests in this study using Cronbach's Alpha, the decision-making methods using restriction 0.6 . The reliability value of less than 0.6 is unfavorable, whereas 0.7 is acceptable and above 0.8 is good. Here is a reliability test results were processed using SPSS version 23.

Table 5. Reliability Test Results

\begin{tabular}{|l|l|l|l|l|}
\hline No. & Variables & $\begin{array}{l}\text { Cronbach's } \\
\text { Alpha Value }\end{array}$ & $\begin{array}{l}\text { Restric- } \\
\text { tion }\end{array}$ & Note \\
\hline 1 & $\begin{array}{l}\text { Awareness } \\
\text { pay taxes }\end{array}$ & 0.715 & 0.60 & reliable \\
\hline 2 & $\begin{array}{l}\text { Knowledge of } \\
\text { the taxpayer }\end{array}$ & .650 & 0.60 & reliable \\
\hline 3 & $\begin{array}{l}\text { The attitude } \\
\text { of the } \\
\text { taxpayer }\end{array}$ & 0.775 & 0.60 & reliable \\
\hline 4 & $\begin{array}{l}\text { Tax } \\
\text { compliance }\end{array}$ & .853 & 0.60 & reliable \\
\hline
\end{tabular}


Based on the above table can be seen Cronbach's Alpha value of each variable, the value of reliability variable pay taxpayer awareness of 0.715 is more than 0.6 , it can be concluded that the instrument in awareness taxpayers pay otherwise reliable. Knowledge variable reliability value of 0.650 taxpayers more than 0.6 it can be concluded that the instrument on the taxpayer otherwise reliable knowledge. Attitude variable reliability value of 0.775 taxpayers more than 0.6 it can be concluded that the instruments on the attitude of the taxpayer otherwise reliable. Variable reliability value of 0.853 tax compliance is more than 0.6 , it can be concluded that the instrument on tax compliance is declared unreliable.

\subsection{Normality Test Results}

Testing for normality in this study using the test Kolmogorov - Smirnov. The test results of normality can be seen in the table below:

Table 6. Normality Test Results

\begin{tabular}{|l|l|l|l|}
\hline Variables & $Z$ & $\begin{array}{l}\text { Asymp.Sig } \\
\text { (2-tailed) }\end{array}$ & Information \\
\hline $\begin{array}{l}\text { Residual } \\
\text { unstandardi } \\
\text { zed }\end{array}$ & 1.437 & 0.321 & $\begin{array}{l}\text { Residual } \\
\text { Normal } \\
\text { distribution }\end{array}$ \\
\hline
\end{tabular}

In the table above it can be seen that the unstandardized residual value of $p=0.321$ greater than the significance level of 0.05 (p> $0.05)$, it can be concluded that the estimated regression in the distribution of data studied were paying taxpayer consciousness, knowledge of the taxpayer, and the attitude of taxpayers on tax compliance by residual normal distribution and the regression model has to meet the assumptions of normality.

\subsection{Test Results Multicollinearity}

Table 4. Test Results Multicollinearity

\begin{tabular}{|l|l|l|l|}
\hline Variables & $\begin{array}{l}\text { Tolera } \\
\text { nce }\end{array}$ & Vif & Information \\
\hline $\begin{array}{l}\text { Awareness } \\
\text { pay the } \\
\text { taxpayer }\end{array}$ & 0.804 & 1.244 & $\begin{array}{l}\text { Did not happen } \\
\text { Multicollinearity }\end{array}$ \\
\hline $\begin{array}{l}\text { Knowledge of } \\
\text { the taxpayer }\end{array}$ & 0.908 & 1.102 & $\begin{array}{l}\text { Did not happen } \\
\text { Multicollinearity }\end{array}$ \\
\hline $\begin{array}{l}\text { The attitude } \\
\text { of the } \\
\text { taxpayer }\end{array}$ & 0.805 & 1,243 & $\begin{array}{l}\text { Did not happen } \\
\text { Multicollinearity }\end{array}$ \\
\hline
\end{tabular}

Based on data from the table above, the variable consciousness of paying taxes has amounted to 0.804 Tolerance value greater than 0.10 Tolerance limits and has a VIF value at 1.244 which is smaller than the VIF limit of 10 , it can be concluded that the variable pay taxpayer awareness in research this does not happen Multicollinearity. This also occurs on other independent variables such as knowledge of taxpayers and taxpayer attitudes, which have a value greater than the limits Tolerance Tolerance and memilikin VIF smaller than VIF limits. It can be concluded Bahwan regression model in this study did not happen Multicollinearity.

\subsection{Test Results Heterokedastisity}

Here are the test results heteroskedastisity in this study using regression methods glejser:

Table 5. Test Results Heteroskidastity

\begin{tabular}{|l|l|l|}
\hline Variables & Sig. & Information \\
\hline $\begin{array}{l}\text { Awareness pay the } \\
\text { taxpayer }\end{array}$ & 0.061 & $\begin{array}{l}\text { Did not happen } \\
\text { Heteroskidastity }\end{array}$ \\
\hline $\begin{array}{l}\text { Knowledge of the } \\
\text { taxpayer }\end{array}$ & 0.489 & $\begin{array}{l}\text { Did not happen } \\
\text { Heteroskidastity }\end{array}$ \\
\hline $\begin{array}{l}\text { The attitude of the } \\
\text { taxpayer }\end{array}$ & .838 & $\begin{array}{l}\text { Did not happen } \\
\text { Heteroskidastity }\end{array}$ \\
\hline
\end{tabular}

Based on data from the table above, the variable pay taxes consciousness, knowledge of the taxpayer, and the attitude of the taxpayer has a probability (sig) $\mathrm{p}=0.061$, 0.489 , and 0.838 as a whole greater than the significance level of 0.05 , so it can be 
concluded that all three the independent variables are free of symptoms heteroskedastisitas. The conclusion that the regression model in this study did not happen heteroskedastisitas.

\subsection{Hypothesis Test Results}

Testing the hypothesis in this study was conducted to prove the influence of the variables studied. To prove the effect of the studied variables are used multiple linear regression model that includes regression analysis test, t-test, $\mathrm{f}$ and the coefficient of determination (R2). The results of the test with the help of SPSS described sebagamana following description.

Multiple linear regression analysis is used to determine how much influence consciousness of paying taxes (X1), knowledge of the taxpayer (X2), attitude of the taxpayer (X3) on the dependent variable tax compliance (Y). As for the multiple linear regression equation is as follows:

Table 6. Regression Analysis Test

\begin{tabular}{|l|l|l|}
\hline Model & variables & The coefficient (b) \\
\hline $\mathrm{X}$ & Constants & 5.893 \\
\hline $\mathrm{b} 1$ & Awareness Pay & 0.246 \\
\hline $\mathrm{b} 2$ & $\begin{array}{l}\text { Knowledge of the } \\
\text { taxpayer }\end{array}$ & 0,046 \\
\hline b3 & $\begin{array}{l}\text { The attitude of the } \\
\text { taxpayer }\end{array}$ & .415 \\
\hline
\end{tabular}

Source: Data processed, 2016

The coefficient values can be seen in Table 4.9, and then inserted in the multiple linear regression equation, the resulting equation as follows:

$\mathrm{Y}=5,893 \mathrm{X} 1+0.046+0.246+0.415 \mathrm{X} 2$ $\mathrm{X} 3+\mathrm{e}$

Explanation equation coefficient value results were as follows:

a. The constant $\mathrm{a}=5,893$

This means that if the consciousness of paying taxes, knowledge of the taxpayer, the taxpayer dansikap no increase or the value is 0 , then the taxpayer compliance in value by 5,893 ,

b. Coefficient b1 $=0.246$

This means that if the consciousness of paying taxes is increased by 1 unit, then the value of tax compliance will increase by 0.246Assuming satuandengan variables other than consciousness of paying taxes is the knowledge and attitude of the taxpayer worth fixed (constant).

c. The coefficient b2 $=0,046$

This means that if knowledge pay taxes increased by 1 unit, then the value of tax compliance will increase by 0,046 Assuming satuandengan variables other than the knowledge that awareness to pay tax to pay taxes and taxpayer attitudes worth fixed (constant).

d. Coefficient b3 $=.415$

This means that if the attitude of the taxpayer is increased by 1 unit, then the value of tax compliance will increase by .415 Assuming satuandengan variables other than the attitude of the taxpayer that is consciousness of paying taxes and valuable knowledge taxpayers fixed (constant).

\subsection{Test Results t}

Based on the analysis results can be seen the $t$ test results as shown in the following table:

Table 7. Test Results of $t$

\begin{tabular}{|c|c|c|c|}
\hline Variables & $\mathbf{t}$ & t table & Sig \\
\hline $\begin{array}{ll}\text { Consciousness } & \text { of } \\
\text { paying taxes }(\mathrm{X} 1) & \end{array}$ & 3.055 & 2.00 & 0,003 \\
\hline $\begin{array}{l}\text { Knowledge of the } \\
\text { taxpayer (X2) }\end{array}$ & 0.608 & 2.00 & 0,544 \\
\hline $\begin{array}{l}\text { The attitude of the } \\
\text { taxpayer (X3) }\end{array}$ & 4.751 & 2.00 & 0,000 \\
\hline
\end{tabular}

The result of the partial effect ( $t$ test) that have been processed using SPSS version 23 
can be seen in Table 4.10. The result of the calculation of the partial test ( $\mathrm{t}$ test) is as follows:

a. Awareness $t$ test variable Paying Taxes The above test shows that awareness of paying taxes has tcount 3.055> 2.00 ttable, means Ho is rejected, $\mathrm{H} 1$ accepted. In a significant value has a value of $0.003<0.05$. It can be concluded that the variable consciousness of paying taxes have a significant influence on tax compliance variable.

b. Knowledge of variables t test Taxpayers The above test indicates that the knowledge of the taxpayer has $\mathrm{t}_{\text {coun }} \mathrm{t} 0.608<\mathrm{T}_{\text {table }} 2.00$, means that $\mathrm{H}_{\mathrm{o}}$ is accepted, $\mathrm{H} 2$ is rejected. In a significant value has a value of $0.544>$ 0.05 . It can be concluded that the knowledge variable taxpayer does not have a significant influence on tax compliance variable.

c. T test variable Taxpayer Attitude

The above test shows that the attitude of the taxpayer has tcount $4,571>\mathrm{T}_{\text {tabel }} 2.00$, means that $\mathrm{H}_{\mathrm{o}}$ is rejected, $\mathrm{H} 3$ is received. In a significant value has a value of $0.000<0.05$. It can be concluded that the taxpayer attitude variables have a significant influence on the variable tax compliance.

\subsection{Test Results F}

This test is intended to test whether the regression model with the dependent variable and independent variables have statistically significant effect. $F$ test results obtained the following results:

Table 8. Test Results F

\begin{tabular}{lllll}
\hline F count & Ftabel & Sig & Information & \\
\hline 19.293 & 2,84 & 0,000 & $\begin{array}{l}\text { Significant } \\
\text { simultaneously }\end{array}$ & effect \\
\hline Source: Data & & & &
\end{tabular}

Source: Data processed, 2016

Based on the above table the results of the analysis of simultaneous test ( $\mathrm{F}$ test) result Fhitung 19.293 while Ftable value of
2.84. So, $F_{\text {count }}$ greater than $F_{\text {table }}(19.293>$ 2.84). Significant value of 0.000 indicates a lower value than the value of a predetermined significance is $0.05(0.000$ $<0.05)$. Means $\mathrm{H}_{0}$ is rejected, then accepted $\mathrm{H} 4$ can be concluded that the variable consciousness of paying taxes (X1), knowledge of the taxpayer (X2) and the attitude of the taxpayer (X3) simultaneously positive and significant impact on tax compliance (Y).

\subsection{Test Results R2}

The coefficient of determination (R2) essentially measures how far the model's ability to explain variations in the dependent variable. Coefficient of determination is between zero and one. Here are the test results of the coefficient of determination.

\begin{tabular}{|c|c|c|c|}
\hline & $\mathrm{R}$ & R Square & Adjusted R Square \\
\hline 1 & .613 & 0.376 & 0357 \\
\hline
\end{tabular}

According to the table for the calculation atashasil R2 values obtained in multiple regression analysis obtained with a coefficient of determination $\mathrm{R} 2$ value of 0.376 . This means that the percentage contribution of the influence of consciousness of paying taxes, knowledge of the taxpayer, and the taxpayer attitudes toward tax compliance of $37.6 \%$. While the remaining $62.4 \%$ is explained by other factors outside the model studied. Such as salary, motivation, experience, and so forth.

\section{Results}

The results showed awareness of taxpayer variables significantly influence taxpayer compliance. This is in line with research Muliari (2010) and Ratriana Dyah Safri (2013) which states that consciousness 
taxpayers a significant positive effect on compliance cecara individual taxpayers. This proves that the awareness of the taxpayer to pay to the state to fund the national development in the interests of the community, state and nation. Raising awareness of the taxpayer to pay taxes also depend on how the government provides information and services to the community as a taxpayer in order to impress and an erroneous view of the meaning and function of taxes can be eliminated. This proves that increasing awareness of the taxpayer, the higher tax compliance.

The results of the data analysis with partial test for the influence of knowledge taxpayers on tax compliance in mind that there is no significant effect. This is in line with research Mellisa and Mienati (2014) which states that an understanding of tax negative effect on tax compliance. This proves that in meeting on tax compliance do not need to have a high knowledge about taxes. Knowledge of tax laws communities through formal and non formal education will have a positive impact on the awareness of the taxpayer to pay the tax, but it does not mean that direct people adhere to their obligation to pay taxes.

Testing of the third hypothesis in this study shows that the attitude variable taxpayer has a significant influence on tax compliance. This is in line with research Istika Herlina Ulfa (2012) which states that the attitude of the taxpayer (X3) have a significant influence on tax compliance. This proves that the attitude has an important role behaviors to carry out an action that is obedient, particularly in relation to the consciousness of paying taxes, the attitude of the taxpayer shows that taxpayers who either should perform an action or adhere to the existing provisions are provisions in undergoing the obligation to pay tax.

This study contradicts with Ulfa Herlina Istika study (2012) which states that the awareness of the taxpayer does not significantly influence taxpayer compliance. As well as research conducted Timoria Febri Putri Kusuma (2013) on the effect of the tax knowledge and perception of taxpayers on tax compliance which states that knowledge of a significant effect on tax compliance.

In this study, there is also a simultaneous effect of three variables on tax compliance. This means that the percentage contribution of the influence of consciousness of paying taxes, knowledge of the taxpayer, and the taxpayer attitudes toward tax compliance of $37.6 \%$. While the remaining $62.4 \%$ is explained by other factors outside the model studied. Such as salary, motivation, experience, and so forth.

In this study it was found that the most influential variable is the attitude variable taxpayer (X3), has the most dominant influence, affecting among other variables on tax compliance can be seen based on the value of beta coeffisien standards for 0415 . As for the variable tax knowledge (X2) does not have a significant impact on taxpayer compliance value is lowest among other variables. It can be seen based on the value of standards coeffisien beta of 0.046 .

\section{Conclusion}

Based on the results of data analysis and discussion conducted in the previous section, this study resulted in:

a. Effect of Paying Taxes Awareness Against Taxpayer Compliance. The results showed that awareness of paying taxes partially positive significant effect on tax compliance. This proves that 
increasing awareness of the taxpayer, the higher tax compliance.

b. Effect of Tax Knowledge Against Taxpayer Compliance. The results of data analysis showed that knowledge does not significantly tax on tax compliance. This proves that in meeting on tax compliance do not need to have a high knowledge about taxes. Knowledge of tax laws of society through awareness will positively affect the consciousness of the taxpayer to pay taxes.

c. Effect Taxpayer Attitude Against Taxpayer Compliance. Testing of the third hypothesis in this study indicate that the partial attitude of the taxpayer has a significant positive effect on tax compliance.

d. Based on data analysis found that the variable Taxpayer Awareness (X1), Knowledge Taxes (X2), Taxpayer Attitude (X3), simultaneously affect the tax compliance (Y). The amount of variation that occurs in the independent variable is $37.6 \%$. While the remaining $62.4 \%$ is explained by other variables used in this regression equation.

e. In this study it was found that the taxpayer attitude variable (X3) has the most dominant influence, affecting among other variables on tax compliance can be seen based on the value of beta coeffisien standards for 0415 .

\section{Refference}

Arum, Harjanti Puspa 2012. Influence of Consciousness Taxpayer Services tax authorities, and Sanctions Against Tax Compliance Personal Tax Payer who Perform Work Free. Thesis S1. Semarang: Diponegoro University.
Wirawan B. Ilyas, Rudi Suhartono. 2007. Income Tax. Issuing Jakarta: Faculty of Economics, University of Indonesia.

Brotodiharjo, R, Santosa. Introduction to Tax Law. Bandung: Rafika Aditama. 2003.

Devano. 2006. Taxation, Concepts, Theories and Issues. Jakarta: Kencana.

Ernawati, Sri. 2013. Effect of Tax Payer Against Success Factors Income Tax Receipts. Thesis. STO Banjarmasin: College of Economics Indonesia.

Fikriningrum. 2012. Analysis of Factors Affecting Individual Taxpayer Compliance Obligations Pay Taxes In A Case Study of Primary Service Office of Semarang. Essay. Semarang: Faculty of Economics and Business, University of Diponegoro.

Ghozali, Imam. 2006. Applications Multivariate Analysis with SPSS. Semarang:

Publisher Agency Diponegoro University.

Gujarati, Damodar N. 2015. Fundamentals Ekonomitrika. Book II. Fifth edition. South Jakarta: Salemba Four.

Gunadi. 2005. Tax Accounting. Jakarta: PT Gramedia Widiasarana.

Ibn Hagar. 1996. Fundamentals Quantitative Research Methodology in Education. Jakarta: King Grafindo Persaja.

Irianto, SE 2005. Political Taxation. Building a Democratic State. Yogyakarta: UII Press.

Jatmiko, Agus Nugroho. 2006. Influence Taxpayer Attitude on Implementation 
of Sanctions Fines, service tax authorities, and awareness of the Taxpayer Compliance Taxation Empirical Study Against the individual taxpayer. Thesis. Semarang: Diponegoro University Master of Accounting.

Mardiasmo. 2011. Taxation. Revised Edition 2011. Yogyakarta: Andi.

Muliari. 2010. Perceptions About Tax And Penalties Taxpayer Awareness And Financial Condition Reporting Against Taxpayer Compliance. Accounting journal.

Muliari, NK, Setiawan PE 2010. Influence Perceptions About Sanctions Taxation Taxpayer Awareness and Compliance Reporting In individual taxpayer in East Denpasar STO. Accounting journal.

Musyarofah, Siti and Adi Purnomo. 2008. Effect of Awareness and Perceptions of sanctions, and Desire Pay Taxes on Taxpayer Compliance. JAMBSP. Vol. 5 No. 34-50 Oct. 1, 2008)

Novak, Norma D. 1989. Tax Administration in Theory and Practice London: Preager Publisher.

Nugroho. 2012. Factors affecting willingness to pay taxes with consciousness of paying taxes as an intervening variable (A case study individual taxpayers who perform independent activities listed on STO Middle Semarang One). Journal of Accounting Diponegoro. Vol.1 No.2. 111)

Rantung, Tatiana Vanessa. 2009. Impact of the Sunset Policy Factors - Factors Affecting Willingness to Pay Taxes. Thesis. STO Salatiga: Discourse Satya Christian University, Salatiga.
Robbinson, Stephen. P. 2001. Organizational Behavior Concepts, Controversies, Applications. Jakarta: Prenhallindo.

Safri, Ratriana Dyah. 2013. Effect on Compliance Awareness taxpayer individual taxpayer who perform free work. Thesis. STO Yogyakarta: Yogyakarta State University.

Sekaran, Uma. 2014. Research Methodology for Business. Jakarta: Four Salemba.

Suandy, Erly. 2008 Tax Law. The fourth edition. Jakarta: Four Salemba.

Sugiyono. 2012. Qualitative and Quantitative Research Methods R \& D. Bandung: Alfabeta.

Sulud Kahono. 2003. Influence Taxpayer Attitude Against Taxpayer Compliance In Building Land Tax Payments. Thesis. Empirical Studies on the United Nations Regional KP Semarang: Postgraduate Program Diponegoro University Master of Science in Accounting.

Supadmi. 2010. Improving Quality Through Taxpayer Compliance. Journal of Accounting and Business: Faculty of Economics, University of Udayana.

Supriyati. 2009. Impact of Motivation and Knowledge Against Taxation Taxpayer Compliance. Sumihar Petrus Tambunan (2003). Why do we pay taxes. Tax News. No.1488 / Year XXXV. p. 33-35)

Suyapto, Mellisa and Mienati Somya Lasmana. 2014. Analysis of Factors Affecting Taxpayer Compliance Board at the Regional Office of Directorate General of Taxes in East Java. Airlangga University. Accounting journal.

Suyatmin. 2004. Influence Taxpayer Attitude Against Taxpayer Compliance In Building Land Tax Payments. Thesis. Empirical Studies on the United Nations 
Regional KP Surakarta: Postgraduate Program Diponegoro University Master of Science in Accounting.

Torgler, Benno. 2008. Introduction to the Special Issue on complience Tax and Tax Policy, Ekonomy Analysis and Policy, The School of Economic and Finance. March, 38 (1). Queensland University of Technology Australia.

Ulfa, Istika Herliana. 2015. Effect of Awareness, Knowledge and Attitude Tax Taxpayers Against the Taxpayer Compliance Bebas.Tesis job. The STO Semarang.

Utomo, Bayu Ageng Revelation. 2011. Effect of Attitudes, Awareness and Knowledge Taxpayer Tax to Pay Taxpayer Compliance in land and building tax. Essay. in the District of South Tangerang city Pamulang: Faculty of Economics and Business. UIN.

Waluyo. 2008. Taxation Indonesia. Eight Edition. Jakarta: Salemba four.

Widayati and Nurlis. 2010. Factors Affecting Pay Taxes For the individual taxpayer who Perform Work Free. Case Study Three STO Gambir. Purwokerto. Accounting journal. 